\title{
Penerapan Model Pembelajaran Inkuiri untuk Meningkatkan Motivasi dan Hasil Belajar Siswa pada Materi Cahaya dan Sifat-Sifatnya di SD Negeri 2 Uebone
}

\author{
Harni \\ SD Negeri 2 Uebone, Kabupaten Tojo Una Una - Provinsi Sulawesi Tengah \\ Corresponding Author. Email: Harnisetia63@gmail.com
}

\begin{abstract}
This study aims to improve student motivation and learning outcomes through the application of inquiry learning models. The research method used was classroom action research that adapted the Kemmis \& Mc. Model. Taggart with two cycles. The subjects of this study were students of grade IV SD Negeri 2 Uebone, totaling 28 students. Data collection techniques using tests, observation and documentation. The data analysis technique was processed by descriptive analysis. The results of research using the inquiry method showed that the motivation and learning outcomes of students had increased. The increase in student learning motivation from the initial conditions of $30 \%$ or $35.71 \%$ or 10 students increased to 18 students or $64.29 \%$ and reached $100 \%$ of the $85 \%$ minimum limit that had been determined in the success criteria of the learning improvement process in the second cycle, and the increase in student learning outcomes from the average in the initial conditions of 57.50 increased to 64.64 in the first cycle and at the end of the second cycle increased to 77.86 and the completeness of learning in the initial conditions was 6 students $(21.43 \%)$, After the improvement was carried out by the application of the inquiry method in the first cycle it increased to 15 students or $53.57 \%$ and in the second cycle it increased again to 26 students or $92.86 \%$.
\end{abstract}

Abstrak: Penelitian ini bertujuan untuk meningkatkan motivasi dan hasil belajar siswa melalui penerapan model pembelajaran inkuiri. Metode penelitian yang digunakan adalah penelitian tindakan kelas yang mengadaptasi model Kemmis \& Mc. Taggart dengan dua siklus. Subjek penelitian ini adalah siswa kelas IV SD Negeri 2 Uebone yang berjumlah 28 siswa. Teknik pengumpulan data menggunakan tes, observasi dan dokumentasi. Teknik analisa data diolah dengan analisis deskriptif. Hasil penelitian dengan menggunakan metode inkuiri menunjukkan bahwa motivasi dan hasil belajar siswa mengalami peningkatan. Peningkatan motivasi belajar siswa dari kondisi awal sebesar 30\% atau 35,71\% atau 10 siswa meningkat menjadi 18 siswa atau 64,29\% dan mencapai angka $100 \%$ dari $85 \%$ batasan minimal yang telah ditentukan pada kriteria keberhasilan proses perbaikan pembelajaran pada siklus kedua, dan peningkatan hasil belajar siswa dari rata-rata pada kondisi awal sebesar 57,50 meningkat menjadi 64,64 pada siklus I dan pada akhir siklus II meningkat menjadi 77,86 serta ketuntasan belajar pada kondisi awal sebanyak 6 siswa $(21,43 \%)$, setelah dilaksanakan perbaikan dengan penerapan metode inkuiri pada siklus I meningkat menjadi 15 siswa atau 53,57\% dan pada siklus II meningkat kembali menjadi 26 siswa atau $92,86 \%$.
Article History

Received: 29-01-2021

Revised: 09-03-2021

Published: 04-04-2021

\section{Key Words:}

Motivation, Learning

Outcomes, Inquiry

Learning Models.

\section{Sejarah Artikel}

Diterima: 29-01-2021

Direvisi: 09-03-2021

Diterbitkan: 04-04-2021

\section{Kata Kunci:}

Motivasi, Hasil Belajar, Model Pembelajaran Inkuiri.

How to Cite: Harni, H. (2021). Penerapan Model Pembelajaran Inkuiri untuk Meningkatkan Motivasi dan Hasil Belajar Siswa pada Materi Cahaya dan Sifat-Sifatnya di SD Negeri 2 Uebone. Jurnal Paedagogy, 8(2). doi:https://doi.org/10.33394/jp.v8i2.3481

https://doi.org/10.33394/jp.v8i2.3481

This is an open-access article under the CC-BY-SA License.

\section{Pendahuluan}

Pendidikan merupakan sesuatu yang dinamis selalu ada perubahan-perubahan yang disesuaikan dengan perkembangan zaman dan kebutuhan masyarakat. Salah satunya adalah perubahan kurikulum tingkat satuan pendidikan (KTSP) ke kurikulum 2013. Perubahan yang 
terjadi merupakan usaha perbaikan sistem pendidikan di Indonesia. Kurikulum 2013 merupakan perangkat mata pelajaran dan program pendidikan berbasia sains yang diberikan oleh suatu lembaga penyelenggara pendidikan dengan tujuan untuk mempersiapkan lahirnya generasi emas bangsa indonesia, dengan sistem dimana siswa lebih aktif dalam kegiatan belajar mengajar. Titik beratnya, kurikulum 2013 ini bertujuan untuk mendorong peserta didik atau siswa agar lebih baik dalam melakukan observasi, bertanya, bernalar, dan mempresentasikan apa yang mereka peroleh atau mereka ketahui setelah meneerima materi pembelajaran. Adapun obyek yang menjadi pembelajaran dalam penataan dan penyempurnaan kurikulum 2013 menekankan pada fenomena alam, sosial, seni, dan budaya. Berbeda dengan kurikulum sebelumnya, kurikulum 2013 lebih menekankan pada ketiga aspek, yaitu menghasilkan peserta didik berakhlak mulia (afektif), berketerampilan (psikomotorik), dan berpengetahuan (kognitif) yang berkesinambungan. Sehingga diharapkan agar siswa lebih kreatif, inovatif dan lebih produktif. Pembelajaran yang menuntut keterlibatan siswa ini sesuai dengan Kurikulum 2013 yang menekankan pada peran aktif siswa dan guru sebagai fasilitator dalam proses pembelajaran (Kurniasih \& Sani, 2014). Pembelajaran yang mengacu pada standar proses pendidikan harus mampu memfasilitasi pengembangan potensi siswa, maka diperlukan proses pembelajaran yang mengarah pada penekanan aktivitas belajar ke arah siswa sehingga siswa secara aktif dapat mengembangkan potensi yang mereka miliki (Budiningsih, 2005; Anisah, 2020; Suarni dkk, 2021)

Dalam kurikulum 2013 juga terdapat strategi pengembangan pendidikan, salah satunya adalah penambahan jam pelajaran. Rasionalitas penambahan jam pelajaran dapat dijelaskan bahwa perubahan proses pembelajaran (dari siswa diberitahu menjadi mencari tahu) dan proses penilaian (dari berbasis output menjadi berbasis proses dan output) memerlukan tambahan jam pelajaran. Dengan alokasi waktu per jam pelajaran. Kurikulum 2013 adalah kurikulum yang melakukan penyederhanaan, dan tematik-integratif, menambah jam pelajaran dan bertujuan untuk mendorong peserta didik atau siswa, mampu lebih baik dalam melakukan observasi, bertanya, bernalar, dan mengkomunikasikan (mempresentasikan), apa yang mereka peroleh atau mereka ketahui setelah menerima materi pembelajaran dan diharapkan siswa kita memiliki kompetensi sikap, keterampilan, dan pengetahuan jauh lebih baik. Mereka akan lebih kreatif, inovatif, dan lebih produktif, sehingga nantinya mereka bisa sukses dalam menghadapi berbagai persoalan dan tantangan di zamannya, memasuki masa depan yang lebih baik.

Dalam kurikulum 2013 buku teks disebut buku tematik dimana beberapa mata pelajaran disatukan dalam sebuah tema. Misalnya mata pelajaran IPA, dahulu IPA menjadi mata pelajaran tersendiri sekarang masuk kedalam muatan tema yang diajarkan secara bersama-sama dengan muatan mata pelajaran lainnya. Dalam kurikulum 2013 terdapat dua buku tematik yaitu buku guru dan buku siswa. Menurut Panduan teknis memahami buku guru dan buku siswa "Buku Guru adalah panduan bagi guru dalam melaksanakan pembelajaran di kelas. "Buku siswa adalah buku yang diperuntukan bagi siswa yang dipergunakan sebagai panduan aktifitas pembelajaran untuk memudahkan siswa dalammenguasai kompetensi tertentu." Oleh karena itu, buku siswa haruslah sesuai dengan kompetensi yang telah ditetapkan.

Selama ini, antusiasme siswa dalam mengikuti pelajaran IPA di sekolah tidak seperti mengikuti pelajaran lainnya. Siswa berpendapat bahwa pelajaranIPA merupakan pelajaran hapalan sehingga motivasi mereka untuk antusias terhadap mata pelajaran ini sering dianggap sepele. Bagi siswa, konsep dan prinsip IPA mudah untuk dipahami sendiri di rumah dan terkesan membosankan. Hal ini berdampak pada rendahnya minat siswa untuk belajar IPA. 
Masalah ini merupakan salah satu masalah klasik yang kerap dijumpai oleh para guru di sekolah.

Ketidaksukaan pada pelajaran IPA, dapat berdampak pula pada sikap siswa terhadap gurunya. Tidak sedikit guru yang kurang mendapat simpati dari para muridnya karena ketidakberhasilan siswa dalam belajar IPA. Nilai yang buruk dalam tes formatif dan sumatif IPA menempatkan guru sebagai penyebab kegagalan dimata siswa dan orang tua. Sikap siswa akan sangat berbeda pada guru kesenian atau olahraga misalnya, pelajaran yang menjadi favorit bagi kebanyakan siswa.

Realita yang terjadi di lapangan, hasil belajar siswa kelas IV SDN 2 Uebone pada pembelajaran IPA masih rendah. Hal tersebut terbukti dengan nilai pada kegiatan pra-siklus yang diadakan di kelas IV SDN 2 Uebone pada materi cahaya dan sifat-sifatnya didapatkan sebanyak 6 dari 28 siswa atau 21,43\% yang masih mendapatkan nilai di atas KKM (Kriteria Ketuntassan Minimal) dan sisanya 22 siswa atau sekitar 78,57\% sudah mencapai nilai diatas KKM yaitu 70. Masih belum optimal hasil belajar siswa tersebut dapat disebabkan oleh beberapa faktor salah satunya dalam pembelajaran IPA masih bersifat sekedar materi atau penjelasandari guru sehingga siswa tidak dilatih untuk mampu mencari permasalahan dan memecahkannya sendiri, siswa diharapkan hanya untuk mengerti konsep tanpa bereksperimen untuk menemukan fakta dan penemuan dari konsep yang telah diajarkan.Keadaan ini berdampak negatif yang dapat menyebabkan motivasi dan hasil belajar siswa kelas IV SDN 2 Uebone rendah. Sesuai dasar pemikiran dan fakta diatas dapat disimpulkan bahwa masih kurangnya kualitas pembelajaran IPA maka perlu adanya pemecahan permasalahan tersebut.

Pemecahan permasalahan tersebut ialah dengan menerapkan pembelajaran bermodel inkuiri. Model pembelajaran inkuiri dimulai dengan suatu kejadian yang menimbulkan teka teki pada siswa. Inkuiri berarti pertanyaan atau penyelidikan. Piaget (dalam Seprianingsih, 2017) menyatakan model pembelajaran inkuiri sebagai "Pendidikan yang mempersiapkan situasi bagi anak untuk melakukan eksperimen sendiri". Mengajukan pertanyaan-pertanyaan dan mencari jawaban atas pertanyaan yang mereka ajukan. Model pembelajaran inkuiri adalah model pembelajaran penemuan. Siswa akan dituntut untuk menemukan serta mencari jawaban atas suatu permasalahan yang tentunya dilakukan dengan cara sistematis, logis dan kritis dan dianalisis dengan perhitungan yang matang. Menyimak ulasana tersebut, model pembelajaran inkuiri jelas akan lebih menjadikan siswa untuk selalu terlibat dan banyak berdiskusi dalam penerapannya. Guru disini hanya menjadi seorang fasilitator selebihnya murid yang lebih berperan. Berkenaan dengan model pembelajaran inkuiri, ada 2 macam jenis model ini yaitu model pembelajaran inkuiri terbimbing dan model pembelajaran inkuiri terikat. Secara garis besar terdapat 5 langkah pada model pembelajaran inkuiri ini, yaitu orientasi, merumuskan masalah, merumuskan hipotesis, mengumpulkan data, merumuskan kesimpulan dan menguji hipotesis. Joyce dan Weil (dalam Nurkhasanah, 2019) mengemukakan bahwa inti dari pembelajaran Inkuiri adalah melibatkan peserta didik dalam masalah penyelidikan nyata dengan menghadapkan mereka dengan cara penyelidikan (investigasi).

Penerapan pembelajaran bermodel inkuiri dilakukan oleh guru dengan membimbing siswa memanfaatkan sarana dan fasilitas di lingkungan sekitar sekolah. Pembelajaran bermodel inkuiri ini dilakukan sebagai salah satu upaya untuk meningkatkan motivasi dan hasil belajar IPA siswa kelas IV SDN 2 Uebone Salah satu keunggulan dari model pembelajaran inkuiri yaitu dapat meningkatkan motivasi dan hasil belajar siswa. Hal ini dikarenakan siswa diberi kesempatan untuk mencari dan menemukan sendiri jawaban atas 
permasalahan yang diberikan melalui pengamatan dan pengalaman dari siswa itu sendiri (Putra, 2013; Trianto, 2011).

Adapun tujuan penelitian ini adalah untuk meningkatkan motivasi dan hasil belajar siswa melalui penerapan model pembelajaran inkuiri di kelas IV SD Negeri 2 Uebone.

\section{Metode Penelitian}

Penelitian ini menggunakan metode penelitian tindakan kelas (PTK). Penelitian ini ditempuh melalui dua siklus dengan dua pertemuan pada setiap siklusnya. Dalam melaksanakan penelitian ini tiap siklus terdiri atas empat tahapan, yaitu: perencanaan, pelaksanaan, observasi, dan refleksi (Arikunto dkk, 2012). Tahapan dalam penelitian ini dalam bentuk diagram gambar adalah sebagai berikut :

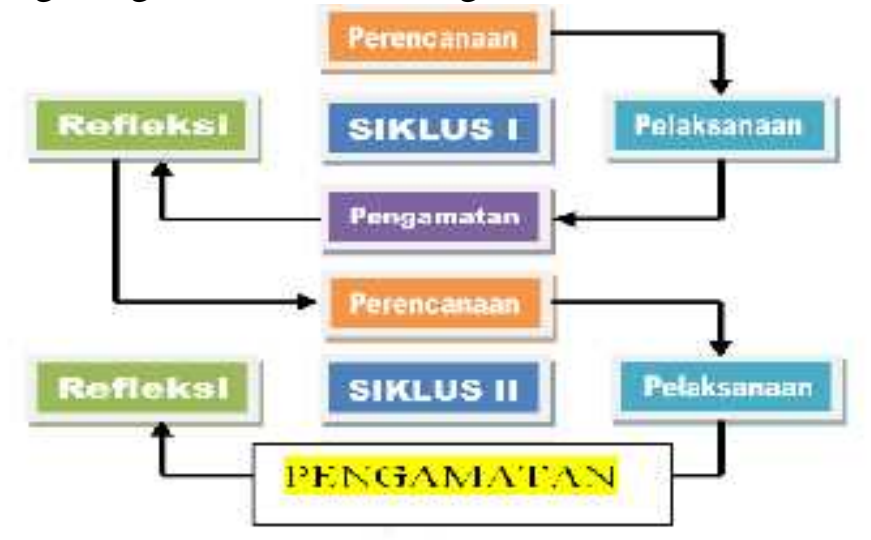

Gambar 1. Bagan Pelaksanaan PTK (Arikunto dkk, 2012)

Subjek penelitian dalam penelitian ini adalah siswa kelas IV SDN 2 Uebone Semester 1 Tahun Pelajaran 2020/2021 dengan jumlah siswa sebanyak 28. Teknik pengumpulan data penelitian ini menggunakan lembar observasi, tes, dan dokumentasi. Untuk menjamin kebenaran data yang dikumpulkan dan dicatat dalam penelitian maka dipilih dan ditentukan cara-cara yang tepat untuk mengembangkan validitas data yang diperolehnya. Dalam penelitian ini akan digunakan teknik triangulasi. Menurut Moeleong (2000) Triangulasi adalah teknik pemeriksaan keabsahan data yang memanfaatkan sesuatu yang lain di luar data itu, untuk keperluan pengecekan atau sebagai pembanding terhadap data tersebut. Pada penelitian tindakan kelas, data dianalisis sejak tindakan pembelajaran dilakukan, dilambangkan selama proses refleksi sampai proses penyusunan laporan. Analisis data ini dilakukan secara kualitatif melalui tiga alur. Menurut Miles dan Hubermen (2014) alur yang meliputi reduksi data, penyajian data dan penarikan kesimpulan atau verifikasi.

Kriteria keberhasilan yang digunakan untuk mengukur tingkat keberhasilan proses pembelajaran dalam penelitian tindakan kelas ini yakni; (1) Siswa dinyatakan tuntas apabila telah menguasai materi sedikitnya $85 \%$ atau mendapat nilai 70. (2) Hasil belajar siswa dalam pembelajaran dinyatakan berhasil jika $85 \%$ jumlah siswa tuntas belajar. (3) Proses perbaikan pembelajaran dinyatakan berhasil jika peningkatan motivasi belajar siswa mencapai $85 \%$ lebih dari jumlah siswa.

\section{Hasil Penelitian dan Pembahasan}

Penerapan model pembelajaran inkuiri ini telah membantu dalam meningkatkan motivasi belajar siswa, hal ini terbukti dari hasil belajar yang diberikan pada setiap siklusnya mengalami peningkatan. Rekapitulasi nilai hasil tes formatif siswa dari kondisi awal, siklus I sampai dengan siklus II dapat dilihat dari tabel di bawah ini. 
Tabel 1. Rekapitulasi Nilai Tes Formatif Temuan Awal, Siklus I dan Siklus II

\begin{tabular}{|c|l|c|c|c|c|c|}
\hline \hline \multirow{2}{*}{ No } & \multirow{2}{*}{ Uraian } & \multirow{2}{*}{ Nilai } & \multicolumn{2}{|c|}{ Siswa Belum Tuntas } & \multicolumn{2}{c|}{ Siswa Tuntas } \\
\cline { 4 - 7 } & & & Frekuensi & $\%$ & Frekuensi & $\%$ \\
\hline 1 & Awal & 57,50 & 6 & 21,43 & 22 & 78,57 \\
\hline 2 & Siklus I & 64,64 & 15 & 53,57 & 13 & 46,43 \\
\hline 3 & Siklus II & 77,86 & 26 & 92,86 & 2 & 7,14 \\
\hline \hline
\end{tabular}

Untuk memperjelas kenaikan ketuntasan belajar siswa dan penurunan ketuntasan belajar siswa dapat dilihat pada diagram batang di bawah ini :

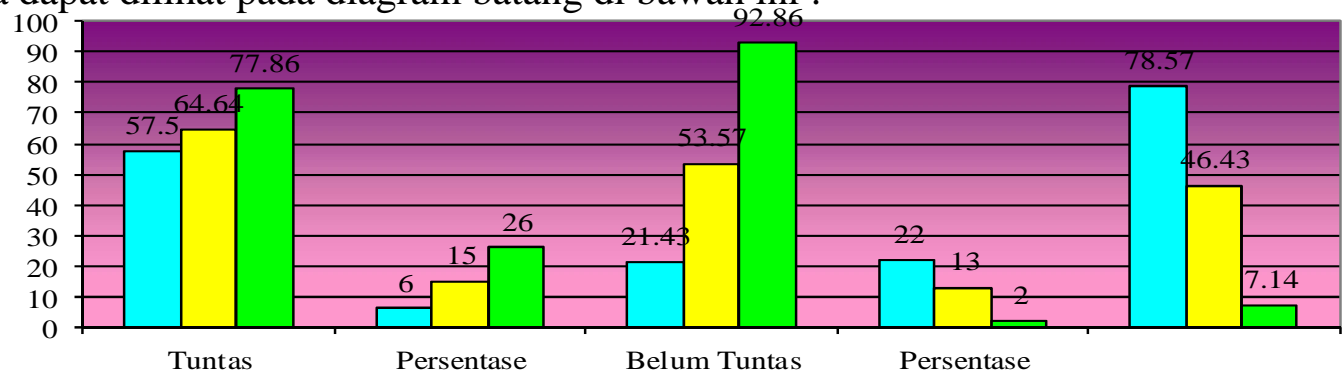

\section{Gambar 2. Grafik Peningkatan dan Penurunan Ketuntasan Belajar Siswa pada Studi Awal, Siklus I dan II}

Dari gambar di atas dapat diketahui bahwa sebelum dilaksanakan perbaikan pembelajaran melalui penerapan penerapan metode inkuiripada pembelajaran IPAmateri cahaya dan sifat-sifatnya, jumlah siswa yang tuntas belajarnya pada keadaan awal sebanyak 6 siswa $(21,43 \%)$, setelah dilaksanakan perbaikan dengan penerapan metode inkuiri pada siklus I meningkat menjadi 15 siswa atau 53,57\% dan pada siklus II meningkat kembali menjadi 26 siswa atau 92,86\%. Adapun penjelasan mengenai penurunan siswa yang belum tuntas belajarnya pada keadaan awal sebanyak 22 siswa atau 78,57\%, setelah dilaksanakan perbaikan dengan penerapan penerapan metode inkuiri pada siklus I menurun menjadi 13 siswa atau 46,43\% dan pada siklus II menurun menjadi 2 siswa atau 7,14\%.

Penjelasan mengenai peningkatan nilai rata-rata hasil belajar pada pembelajaran IPAdengan penerapan metode inkuiri menunjukkan peningkatan yang cukup signifikan di mana pada kondisi awal sebesar 57,50 meningkat menjadi 64,64 pada siklus I dan pada akhir siklus II meningkat menjadi 77,86. Peningkatan nilai rata-rata hasil belajar siswa dalam bentuk grafik sebagaimana gambar di bawah ini :

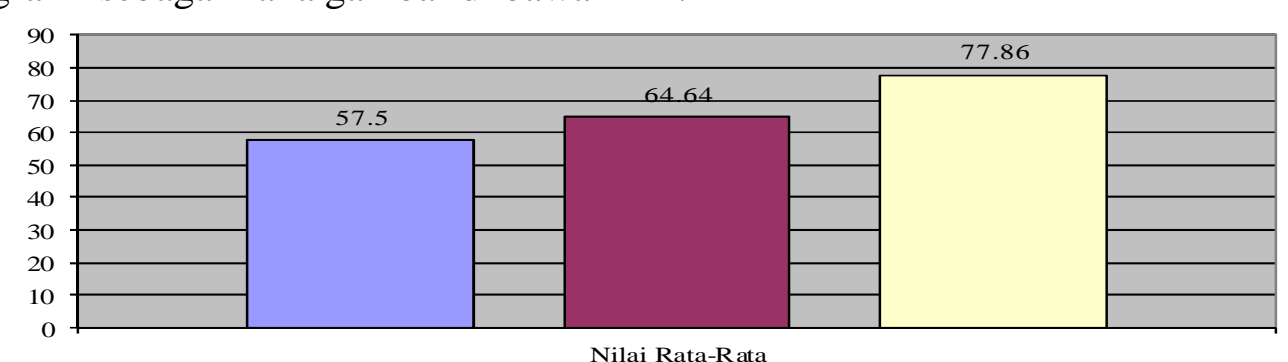

Nilai Rata-Rata

口Awal 口Siklus I ㅁ Siklus II

Gambar 3. Grafik Peningkatan Rata-rata Hasil Belajar Siswa pada Studi Awal, Siklus I dan II 
Keberhasilan proses perbaikan pembelajaran tidak hanya dilihat dari peningkatan prestasi belajar atau nilai tes formatif saja. Motivasi belajar siswa selama proses pembelajaran juga merupakan indikator keberhasilan dalam proses pembelajaran. Data motivasi siswa diperoleh dari lembar observasi yang telah diisi oleh observer selama perbaikan pembelajaran berlangsung. Fokus observasi difokuskan pada tekun menghadapi tugas dan ulet menghadapi kesulitan, tidak memerlukan dorongan dari luar untuk berprestasi, ingin mendalami bahan atau bidang pengetahuan yang diberikan, selalu berusahan berprestasi sebaik mungkin serta menunjukkan minat terhadap macam-macam masalah.Hasil observasi pada pelaksanaan kegiatan perbaikan pembelajaran menunjukkan hasil yang positif, dan dibuktikan dengan adanya peningkatan motivasi siswa pada setiap siklusnya. Secara rinci penjelasan mengenai peningkatan motivasi siswa dalam proses perbaikan pembelajaran sebagaimana tabel di bawah ini :

Tabel 2. Rekapitulasi Peningkatan Motivasi Siswa pada Siklus I dan Siklus II

\begin{tabular}{cccccc}
\hline \multirow{2}{*}{ No } & Siklus & \multicolumn{2}{c}{ Tuntas } & \multicolumn{2}{c}{ Belum Tuntas } \\
\cline { 3 - 6 } & & $\begin{array}{c}\text { Jumlah } \\
\text { Siswa }\end{array}$ & Persentase & $\begin{array}{c}\text { Jumlah } \\
\text { Siswa }\end{array}$ & Persentase \\
\hline $\mathbf{1}$ & Awal & 10 & 35,71 & 18 & 64,29 \\
$\mathbf{2}$ & Siklus I & 18 & 64,29 & 10 & 35,71 \\
$\mathbf{3}$ & Siklus II & 28 & 100,00 & 0 & 0,00 \\
\hline
\end{tabular}

Secara jelas peningkatan motivasi siswa selama proses perbaikan pembelajaran sebagaimana dijelaskan pada gambar di bawah ini :

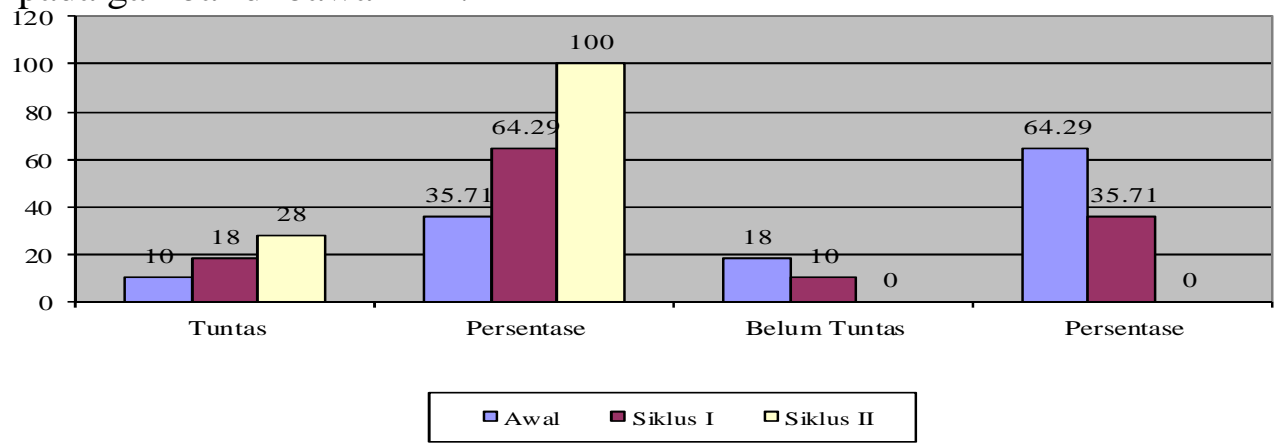

\section{Gambar 4. Grafik Ketuntasan Siswa Berdasarkan Tingkat Motivasi Siswa pada Siklus I dan II}

Dari hasil observasi mengenai motivasi siswa tersebut berdasarkan kriteria keberhasilan perbaikan pembelajaran dapat disimpulkan bahwa proses perbaikan pembelajaran dinyatakan berhasil karena peningkatan motivasi siswa dari kondisi awal sebesar 35,71\% atau 10 siswa meningkat menjadi 18 siswa atau 64,29\% dan mencapai angka $100 \%$ dari $85 \%$ batasan minimal yang telah ditentukan pada kriteria keberhasilan proses perbaikan pembelajaran pada siklus kedua.

\section{Pembahasan}

Penelitian yang telah dilakukan sebanyak dua siklus dengan menerapkan pembelajaran cahaya dan sifat-sifatnya menggunakan metode inkuiri ternyata dapat meningkatkan motivasi dan hasil belajar IPA siswa kelas IV SDN 2 Uebone Tahun Pelajaran 2020/2021 dari kondisi awal, siklus I ke siklus II. Penelitian ini terfokus pada mata pelajaran Ilmu Pengetahuan Alam pada materi cahaya dan sifat-sifatnya. Adapun tujuan dari penelitian ini adalah untuk perbaikan, peningkatan pembelajaran dan pengembangan kemampuan siswa 
menghadapi permasalahan dalam pembelajaran di kelas khususnya motivasi dan hasil belajar siswa. Sebelum proses pembelajaran siklus I, penulis melakukan pengamatan proses belajar mengajar secara konvensional. Kegiatan ini dimulai dengan penjelasan materi, memberi contoh, memberikan tugas, pembahasan kemudian evaluasi. Berdasarkan kegiatan pra siklus yang telah dilakukan, dapat diketahui bahwa masih banyak siswa yang belum tuntas dalam proses pembelajaran. Hal ini terbukti terdapat 6 siswa yang dinyatakan tuntas dalam proses pembelajaran IPA. Dengan demikian, maka 22 siswa lainnya dinyatakan belum tuntas atau mendapat nilai dibawah KKM yaitu 70. Dari hasil pengamatan sebelumnya, selama pembelajaran siswa hanya mendengarkan dan mencatat. Motivasi belajar siswa sangat rendah dibuktikan hanya terdapat 10 siswa atau $35,71 \%$ yang dinyatakan tuntas dinilai dari motivasi belajarnya. Hal tersebut ditandai dengan siswa jarang bertanya apalagi mengutarakan pendapatnya. Pemahaman tentang materi yang disampaikan sangat rendah karena mereka tidak mengalami sendiri dalam mencari dan menemukan suatu jawaban dari masalah yang dihadapi. Akibatnya siswa mengalami kesulitan bila dihadapkan pada suatu pemecahan masalah. Dari hasil tersebut maka perlu dilakukan sesuatu tindakan agar motivasi belajar siswa meningkat.

Dari hasil penelitian pada siklus I dan siklus II menunjukkkan bahwa cara belajar dengan metode inkuiri memiliki dampak positif dalam meningkatkan motivasi dan hasil belajar siswa. Hal ini dapat dilihat dari semakin meningkatnya tingkat ketuntasan dan hasil belajar siswa pada setiap siklusnya. Jika sebelum dilakukan PTK hanya $6(21,43 \%)$ saja yang tuntas tetapi terjadi peningkatan ketuntasan belajar pada siklus I sebesar 53,57\% Hal ini disebabkan oleh pembelajaran yang menyenangkan dengan menggunakan model pembelajaran Inkuiri dimana siswa sebagai subyek belajar secara berkelompok diberikan kesempatan untuk menyelesaikan permasalahan sendiri dengan media yang mendukung sehingga proses belajar mengajar menjadi lebih efektif. Siklus ke II mengalami ketuntasan dengan prosentase $92,86 \%$ hal ini berarti mengalami ketuntasan dan sesuai dengan KKM. Hal tersebut juga didukung dari peningkatan motivasi belajar siswa dimana pada kondisi awal sebesar $35,71 \%$ atau 10 siswa meningkat menjadi 18 siswa atau 64,29\% dan mencapai angka $100 \%$ dari $85 \%$ batasan minimal yang telah ditentukan pada kriteria keberhasilan proses perbaikan pembelajaran pada siklus kedua.Sesuai dengan hasil refleksi peneliti berusaha mengadakan perbaikan, kali ini siswa dalam kelas sudah terbiasa dengan pembelajaran yang menggunakan metode inkuiri dan dengan antusiasnya menggali pemahaman mereka sendiri, selain itu peneliti juga menyajikan materi yang lebih sederhana dan sesuai dengan tingkat pemahaman siswa.

Berdasarkan data-data hasil pelaksanaan perbaikan pembelajaran sebagaimana diuraikan di atas berupa data hasil tes formatif siklus I, tes formatif siklus II dan data hasil observasi siklus I dan II maka dapat disimpulkan bahwa penerapan metode inkuiri dapat meningkatkan hasil belajar siswa pada pembelajaran IPA di kelas IV SDN 2 Uebone Tahun Pelajaran 2020/2021.

\section{Kesimpulan}

Kesimpulan yang diperoleh dari penelitian ini antara lain adalah; (1) Penerapan model pembelajaran inquiri mampu meningkatkan proses pembelajaran IPA pada materi cahaya dan sifat-sifatnya. Hal tersebut dibuktikan dengan siswa semakin bertanya dan mengutarakan pendapatnya. Pemahaman tentang materi yang disampaikan juga meningkat karena mereka mengalami sendiri dalam mencari dan menemukan suatu jawaban dari masalah yang dihadapi sehingga siswa tidak mengalami kesulitan bila dihadapkan pada suatu pemecahan masalah. 
(2) Penerapan model pembelajaran inquiri mampu meningkatkan hasil dan ketuntasan belajar siswa pembelajaran IPA pada materi cahaya dan sifat-sifatnya. Hal ini dibuktikan dengan peningkatan motivasi belajar siswa dari kondisi awal sebesar 35,71\% atau 10 siswa meningkat menjadi 18 siswa atau 64,29\% dan mencapai angka 100\% dari 85\% batasan minimal yang telah ditentukan pada kriteria keberhasilan proses perbaikan pembelajaran pada siklus kedua. (3) Penerapan model pembelajaran inquiri mampu meningkatkan hasil dan ketuntasan belajar siswa pembelajaran IPA pada materi cahaya dan sifat-sifatnya. Hal ini dibuktikan dengan kenaikan hasil belajar siswa dari rata-rata pada kondisi awal sebesar 57,50 meningkat menjadi 64,64 pada siklus I dan pada akhir siklus II meningkat menjadi 77,86 dan ketuntasan belajar pada kondisi awal sebanyak 6 siswa (21,43\%), setelah dilaksanakan perbaikan dengan penerapan metode inkuiri pada siklus I meningkat menjadi 15 siswa atau 53,57\% dan pada siklus II meningkat kembali menjadi 26 siswa atau 92,86\%.

\section{Saran}

Adapun saran yang dapat disampaikan berdasarkan hasil penelitian ini antara lain adalah;

(1) Bagi Guru

a) Para guru perlu menggunakan pendekatan inkuiri sebagai salah satu cara yang dapat diterapkan di dalam pembelajaran Ilmu Pengetahuan Alam untuk meningkatkan keaktifan belajar Ilmu Pengetahuan Alam

b) Penggunaan metode pembelajaran yang bervariasi harus terus ditingkatkan agar dapat menciptakan pembelajaran yang menyenangkan bagi siswa.

(2) Bagi siswa.

a) Siswa perlu diberi kesempatan untuk melakukan sendiri percobaan sehingga mereka tidak merasa bosan untuk belajar.

b) Siswa harus aktif dalam mengikuti kegiatan pembelajaran melalui peragaan, pengamatan, dan latihan untuk dapat menemukan pengetahuannya sendiri demi meningkatkan hasil belajarnya.

c) Siswa hendaknya berani dalam bertanya, mengemukakan pendapat, atau menanggapi pendapat siswa lain dalam proses diskusi kelompok.

(3) Bagi Sekolah

a) Penggunaan metode inkuiri hendaknya dapat menjadi salah satu upaya untuk mengembangkan sekolah ke arah yang lebih baik terutama kualitas pembelajaran.

b) Sarana dan prasarana serta fasilitas pembelajaran harus dioptimalkan agar tidak menghambat proses pembelajaran sehingga dapat meningkatkan mutu pendidikan di sekolah.

\section{Daftar Pustaka}

Anisah, N. (2020). Upaya Peningkatan Minat Baca dan Pengetahuan Siswa Melalui Model Pembelajaran Inkuiri di MTs. Miftahul Huda Jleper Demak Jawa Tengah. Jurnal Paedagogy, 7(4), 408-415. doi:https://doi.org/10.33394/jp.v7i4.2947

Arikunto, S, Sukardjono, P Supardi. (2012). Penelitian Tindakan Kelas. Jakarta: Bumi Aksara.

Budiningsih, A. (2005). Belajar Pembelajaran. Jakarta: PT Cipta dan Rineka.

Kurniasih, I \& Sari. (2014). Implementasi kurikulum konsep \& penerapan. Surabaya: Kata Pena.

Hamalik Oemar. (2014). Media Pendidikan. Bandung: PT. Cipta Aditya Bakti. 
Hernawan, A.H. (2007). Pengembangan Kurikulum dan Pembelajaran. Jakarta: Universitas Terbuka.

Idris Harta. (2016). Pengembangan Model-model pembelajaran Matematika di Sekolah Dasar. Yogyakarta: Universitas Negeri Yogyakarta.

Miles, M. B, Huberman, A.M. (2014). Qualitative Data Analysis, A Methods Sourcebook, Edition 3. USA: Sage Publications. Terjemahan Tjetjep Rohindi Rohidi, UI-Press.

Moleong, L.J. (2000). Metodologi Penelitian Kualitatif. Bandung: PT Remaja Rosdakarya.

Nurkhasanah, S. (2019). Penerapan Model Pembelajaran Inkuiri untuk Meningkatan Aktifitas Belajar Siswa pada Mata Pelajaran Ilmu Pengetahuan Alam Kelas IX.A SMP Negeri 1 Gangga. Jurnal Kependidikan: Jurnal Hasil Penelitian dan Kajian Kepustakaan di Bidang Pendidikan, Pengajaran dan Pembelajaran, 5(1), 47-53. doi:https://doi.org/10.33394/jk.v5i1.1393

Purwati, N. (2019). Upaya Meningkatkan Motivasi dan Hasil Belajar IPA Siswa Melalui Penerapan Model Pembelajaran STAD di Kelas Vi SD Negeri 42 Mataram. Jurnal Paedagogy, 6(1), 14-19. doi:https://doi.org/10.33394/jp.v6i1.2525

Putra, Sitiatava Rizema, (2013), Desain Belajar Mengajar Kreatif Berbasis Sains. Diva Press, Yogyakarta

Seprianingsih, D. (2017). Pengembangan Perangkat Pembelajaran Biologi Berbasis Inkuiri Terbimbing dalam Meningkatkan Penguasaan Konsep Biologi Siswa. Jurnal Kependidikan: Jurnal Hasil Penelitian dan Kajian Kepustakaan di Bidang Pendidikan, Pengajaran dan Pembelajaran, 3(1). doi:https://doi.org/10.33394/jk.v3i1.467

Setiarini, A. (2016). Meningkatkan Motivasi dan Hasil Belajar Peserta Didik dengan Mengoptimalkan Penerapan Pendekatan Saintifik Strategi Discovery Learning dan Metode Diskusi di SDN Model Mataram. Jurnal Kependidikan: Jurnal Hasil Penelitian dan Kajian Kepustakaan di Bidang Pendidikan, Pengajaran dan Pembelajaran, 2(1). doi:https://doi.org/10.33394/jk.v2i1.390

Suarni, G., Rizka, M., \& Zinnurain, Z. (2021). Analisis Pengaruh Penerapan Model Pembelajaran Sains Teknologi Masyarakat Terhadap Hasil Belajar Siswa. Jurnal Paedagogy, 8(1), 31-38. doi:https://doi.org/10.33394/jp.v8i1.3226

Trianto, (2011), Model-model pembelajaran inovatif berorientasi konstruktivitis, Prestasi Pustaka, Jakarta 